\title{
As Práticas de Leitura das Fãs de Romances Sentimentais no Nordeste do Brasil $^{1}$
}

\author{
Práticas de lectura de fanáticas de la novela sentimental en el Noreste de \\ Brasil
}

Reading practices of sentimental novel fans in northeast Brazil

\author{
Roberta Manuela Barros de Andrade 2 \\ Ricardo Augusto de Sabóia Feitosa ${ }^{3}$ \\ Thiago Mena Barreto ${ }^{4}$
}

\begin{abstract}
Resumo
A presente pesquisa busca investigar as práticas culturais que orientam o consumo feminino dos romances sentimentais no Brasil na contemporaneidade. Interroga-se quem seriam as leitoras destes romances, quais seus modos de ler essas obras e em que contexto suas leituras são praticadas. O objetivo principal consiste em compreender as diferentes formas de apropriação dos romances sentimentais por mulheres de extratos sociais e gerações distintas a partir de entrevistas em profundidade realizadas com uma comunidade de vinte leitoras residentes na cidade de Fortaleza (Ceará, Brasil), selecionadas a partir de sua frequência a livrarias, sebos, bancas de revista e fóruns virtuais de debates dedicados a este gênero literário.
\end{abstract}

Palavras-chave: romance sentimental; mulheres; leitura; Brasil

\section{Resumen}

Esta investigación busca analizar las prácticas culturales que guían el consumo femenino de novelas sentimentales en Brasil en la actualidad. Se cuestiona quiénes serían las lectoras de estas novelas, cuáles son sus formas de leer estas obras y en qué contexto se practican sus lecturas. El reto principal es comprender las diferentes formas de apropiación de novelas sentimentales por mujeres de diferentes orígenes sociales y generaciones basadas en entrevistas en profundidad con una comunidad de veinte lectores que viven en la ciudad de Fortaleza (Ceará, Brasil), seleccionadas de su frecuencia a librerías, revistas y foros virtuales de debates dedicados a este género literário.

Palabras claves: novela sentimental; mujeres; lectura; Brasil

\begin{abstract}
This research aims to investigate the cultural practices that guide the female consumption of sentimental novels in Brazil today. It is questioned who the readers of these novels would be, what their ways of reading these novels are and in what context their readings are practiced. The main objective is to understand the different forms of appropriation of sentimental novels by women from different social backgrounds and generations based on in-depth interviews with a community of twenty readers living in the city of Fortaleza (Ceará, Brazil), selected from its frequency to bookstores, magazine stands and virtual forums of debates dedicated to this literary genre.
\end{abstract}

\footnotetext{
${ }^{1}$ Artigo apresentado no II Congresso Internacional Online de Estudos sobre Culturas, na modalidade online, 2020.

${ }^{2}$ Doutora em Sociologia (Universidade Federal do Ceará). Professora Associada do Curso de Ciências Sociais da Universidade Estadual do Ceará (UECE); Fortaleza, Ceará, Brasil; manubarrosster@gmail.com

3 Doutor em Sociologia (Universidade Federal do Ceará). Professor Adjunto do Núcleo de Design e Comunicação da Universidade Federal de Pernambuco (UFPE/CAA); Caruaru, Pernambuco, Brasil; ricardo.saboia@ufpe.br.

${ }^{4}$ Doutorando em Sociologia do Programa de Pós Graduação em Sociologia da Universidade Estadual do Ceará

(UECE). Professor do Curso de Jornalismo do UNINTA; Sobral, Ceará, Brasil; thiagombv@gmail.com
} 
Key-Words: sentimental novel; women; lecture; Brazil.

\section{Introdução}

No Brasil, as políticas públicas voltadas para o livro e a leitura, presentes pelo menos a partir do século XIX, chegam até o século XXI, numa trajetória que mescla tanto ações centradas no seu controle e repressão $0^{5}$ quanto em tentativas de melhoria de seu acesso e distribuição (CROPANI, 1998). Mas, somente em fins do século XX, houve uma preocupação mais efetiva no que tange às políticas que regem o incentivo à leitura, em especial a partir de programas específicos, que se iniciam particularmente entre os anos 1980 e 1990, muitos deles, perdurando até hoje. Nesta trajetória, destaca-se o Plano Nacional do Livro e da Leitura (PNLL) $^{6}$. O PNLL congregou uma série de programas de incentivo à leitura, anteriores à sua formação, como os programas Pró-Leitura (criado em 1992), Programa Nacional de Incentivo à Leitura (Proler, criado em 1992), o Programa Nacional Biblioteca da Escola (PNBE, criado em 1997), o Programa Nacional do Livro Didático (PNDL, criado em 1985) e as campanhas Fome do Livro (2004) e Viva Leitura (2005).

Dentre os programas de incentivo à leitura, o mais famoso deles, a "Ciranda de Livros", vigorou de 1982 a 1985. O projeto "Viagem de Leitura esteve em vigor de 1986 a 1988 e o "Sala de Leitura" só durou o ano de $1988^{7 "}$. Este foi o grande último projeto de incentivo à leitura no País. Somente treze anos depois, o Governo Federal institui outro projeto, o "Literatura em Minha Casa", de curta duração, entre 2001 e 2004. Porém, as verbas insuficientes e o distanciamento dos gestores federais com os agentes regionais comprometeram o sucesso desses programas, não tendo alcançado, sequer de forma mínima, as metas estipuladas. Assim, as políticas públicas brasileiras, ao longo de todo o século XX, são mais uma política do livro do que de democratização da leitura (COPES, 2007). O que

\footnotetext{
${ }^{5} \mathrm{O}$ controle de atividades culturais e a censura à produção, acesso e consumo de livros foram constantes tanto no Estado Novo de Getúlio Vargas (1937-1945), com o DIP (Departamento de Imprensa e Propaganda) bem como com os governos militares (1964-1985), através, principalmente, do AI-5.

${ }^{6}$ O PNLL, instituído, por portaria em 2006, pelos ministérios da Cultura e da Educação, possui quatro eixos estratégicos: democratização do acesso; fomento à leitura e à formação de mediadores; valorização institucional e incremento de seu valor simbólico e desenvolvimento de uma economia do livro.

${ }^{7}$ O Ciranda de Livros tinha como objetivo levar empresas como a Fundação Roberto Marinho e a Fundação Nacional do Livro, apoiados pela Fundação Nacional do Livro Infanto-Juvenil (FNLIJ), a distribuir livros de literatura infantil e juvenil de qualidade para trinta mil escolas carentes da rede pública de ensino. Já o Viagem de Leitura foi executado com os benefícios da Lei Sarney (1986), distribuiu 60 mil livros de literatura para bibliotecas públicas de todo o País, conveniadas com o Instituto Nacional do Livro- INL, órgão federal criado em 1937.
} 
caracteriza todos estes projetos é estarem vinculados a escolas e bibliotecas, focando essencialmente em crianças e adolescentes.

Neste contexto, as políticas públicas voltadas para o livro se caracterizam por se desvincularem dos hábitos cotidianos de leitura dos brasileiros que se fazem à margem da escola e da biblioteca. Estes programas, ao elegerem a escola como mediação fundamental para a prática de leitura, tendo como pedra angular a biblioteca, dentro ou fora dos espaços escolares, acabam por desconsiderar as expressões da literatura de entretenimento como elementos substanciais para pensar a sua efetivação, uma vez que, tal literatura caminha à margem do circuito da escola e da biblioteca. Por outro lado, não existe, em vigor, nos últimos trinta anos, uma política governamental que dê conta da promoção da leitura para jovens e adultos, qualquer que seja seu extrato social ${ }^{8}$.

A leitura de livros pertencentes à literatura de entretenimento por parte de jovens e adultos, apesar de substancialmente significativa, parece não ter um grande peso na construção dos dados de pesquisa que orientam as políticas públicas para a leitura no País. Estas têm, constantemente, minimizado o papel dessa literatura na formação de leitores. No entanto, o hábito de ler livros oriundos da cultura de massa, em especial, de ler romances sentimentais, é extremamente popular em nosso País. Os romances sentimentais, obras que centram seu enredo em contar histórias de amor, geram um montante anual expressivo em vendas. No Brasil, na listagem dos vinte livros mais vendidos no biênio 2015-2016, pelo site Publishnews ${ }^{9}, 40 \%$ dos exemplares ali nomeados pertenciam à categoria de romances sentimentais ${ }^{10}$. Apesar disso, no Brasil, as políticas públicas têm ignorado sistematicamente as práticas de leitura voltadas para a literatura de entretenimento, em especial, aquelas direcionadas para o consumo de histórias de amor.

A crítica especializada chama de romances sentimentais uma obra de ficção que trata de sentimentos e paixões, com expressões variadas e polissêmicas, com pesos e formatos desiguais. São, pois, histórias de amor que destacam os estados emocionais e os conflitos

\footnotetext{
${ }^{8} \mathrm{O}$ último grande programa governamental voltado para o incremento do hábito de leitura em jovens e adultos, no Brasil, foi o Mobral (Movimento Brasileiro de Alfabetização, criado em 1967). O programa, na visão do governo vigente, era caríssimo. Exigia verbas do Fundo Nacional de Desenvolvimento da Educação (FNDE), da Receita Federal, através do imposto de renda e da Loteria Esportiva Federal. Criado durante a vigência do regime militar, teve seu fim em 1985, com a abertura política brasileira.
}

${ }^{9}$ O Publishnews é um site especializado em livros de todos os gêneros literários. Além de apresentar notícias sobre lançamentos e autores, o site publica semanalmente listas com os livros mais vendidos nas maiores livrarias brasileiras, divulgando também listagens mensais e anuais.

${ }^{10}$ Disponível $\quad$ em $\quad$ https://www.publishnews.com.br/ranking/anual/9/2016/0/0
https://www.publishnews.com.br/ranking/anual/9/2015/0/0, acesso em 03/09/2018.

e 
internos das personagens muito mais do que as suas ações externas (SAMONÀ, 1980). Estes romances são classificados como literatura de massa, produzida para o entretenimento a partir de uma demanda de mercado destinada a um amplo público consumidor, englobando todas as gerações, gêneros e classes sociais (SODRÉ, 1978).

A leitura de romances, lembramos, acompanha a história da vida privada das mulheres no Brasil. $\mathrm{O}$ ato de ler romances é uma prática incrustada no cotidiano de milhares de brasileiras, de todas as idades e de todos os extratos sociais. O que se modifica, de grupo a grupo, é a frequência, valor e intensidade com a qual a leitura penetra em suas vidas. Dos romances folhetins aos romances de banca de revista, dos livros, com esquemas de marketing modestos aos grandes lançamentos das editoras, do livro impresso ao e-book, a prática se perpetua, formando gerações de mulheres em nosso País. Porém, pouco sabemos ainda como se dá esta prática, que mecanismos culturais orientam seu consumo e como estes sinalizadores vem se transformando de geração a geração. Assim, cabe indagar quem lê tanto romance, como o faz e em que contexto a sua leitura é praticada.

A presente pesquisa teve, assim, o objetivo de compreender as diferentes formas de apropriação dos romances sentimentais por mulheres de extratos sociais e gerações distintas. Neste contexto, elegemos como objeto de análise as práticas de leitura de uma comunidade de leitura ${ }^{11}$ específica, situada no município de Fortaleza, capital do Estado do Ceará, na região nordeste do Brasil. Para isso, selecionamos como ponto central de reflexão, fãs de romances sentimentais, de gerações e posições sociais diferentes, tanto frequentadoras de livrarias, de bancas de revista e de sebos como partícipes de comunidades de leitura virtuais que consomem avidamente tais romances.

\section{Metodologia}

O universo da pesquisa constitui-se de leitoras, prioritariamente, entre os 18 e os 45 anos de idade, selecionadas a partir de visitas a bancas de revistas, livrarias e sebos do centro da cidade de Fortaleza, capital do Estado do Ceará, localizada no Nordeste do Brasil, além de participações em comunidades virtuais de debates de romances sentimentais. Nossas leitoras são atuantes no mundo do trabalho, exercendo ocupações as mais diversas, muitas delas, inclusive, trabalhando em mais de uma atividade laboral. São casadas, divorciadas, viúvas e

\footnotetext{
${ }^{11}$ Nessa pesquisa, trabalhamos com o que Radway (1987) e Fiske (1987) classificam como uma comunidade interpretativa. Comunidades interpretativas significam um espaço no qual os leitores constroem e empregam assunções e estratégias de compreensibilidade, em relação à leitura de um dado gênero, semelhantes, mesmo que, eventualmente, não tenham contato uns com os outros.
} 
solteiras. A maior parte delas não tem filhos. Professam a fé católica, com uma pequena parte constituída de evangélicas. Grande parte das entrevistadas está situada na hierarquia educacional entre o ensino médio completo e o superior incompleto. A renda média dessas mulheres, em sua maioria, se situa entre dois e quatro salários mínimos.

A pesquisa teve como estratégia metodológica inicial a aplicação de questionários para conhecer a posição das entrevistadas na hierarquia social, notadamente acerca dos seus recortes de renda, formação educacional, religião, estado civil, profissão e faixa etária. $\mathrm{Na}$ segunda fase, partimos para a realização de entrevistas, com as mulheres selecionadas no universo da comunidade de leitura da investigação, divididas em etapas distintas e complementares.

Entrevistamos, durante o ano de 2018, vinte mulheres, de extratos sociais, os mais diversificados e faixas etárias as mais diversas. As entrevistas passaram, durante todo este ano, por várias fases distintas, com múltiplas retomadas, seguindo o formato de "entrevista de profundidade" ou "intensiva". Como destaca Souza (2006, p. 722), a principal vantagem dessas entrevistas "reside na possibilidade de se obterem informações pormenorizadas e aprofundadas sobre valores, experiências, sentimentos, motivações, ideias, posições, comportamentos etc dos entrevistados". Estes colóquios, nesta etapa, tinham como foco os hábitos de consumo dessas mulheres, os seus gostos culturais e suas preferências de leitura. Numa etapa posterior, realizamos uma discussão sobre os romances sentimentais propriamente ditos, em geral e sobre os seus prediletos, em particular.

A maior parte das mulheres entrevistadas começou a ler romances de amor na adolescência e prosseguiu na leitura até a contemporaneidade. Nossa comunidade de leitura é, pois, formada, por mulheres cujo conhecimento sobre a forma, estrutura e conteúdo dos romances sentimentais é qualificado, possuindo hábitos regulares de leitura, que as fazem ter grande proximidade com o gênero, podendo ser, pois, classificadas como leitoras competentes. Para Jauss (1978), nesta competência está implícito o horizonte de atenção dos leitores como uma unidade, fundada sobre a experiência compartilhada, que permitiria a compreensão dos sinais textuais postos no texto. O leitor competente indica um tipo de leitura regular que acaba fazendo que estas mulheres tenham uma trajetória histórica com estes livros.

\section{Resultados}

Ao longo das entrevistas, essas mulheres eram capazes de definirem o gênero sentimental, ressaltando suas principais características, comparando enredos e estilos 
literários, fazendo apreciações estéticas sobre os subgêneros nos quais os romances se alocam e julgando a qualidade de livros específicos a partir desses conhecimentos. Algumas chegaram até mesmo a fazer especulações sobre as diferenças nos processos de tradução de obras realizadas em "livros de livraria" e "livros de banca de revista", detectando inclusive, erros no processo de tradução e edição das obras mais populares. O que é interessante se ressaltar é que reproduzem, apesar de jamais terem tido acesso à literatura especializada, as definições de romances de amor mais comumentes aceitas na crítica literária. Por outro lado, suas "companheiras de vício" são atentas a detalhes e minúcias que compõem a obra. A competência narrativa do gênero é assimilada rapidamente, provocando juízos de valor sobre as obras que leem e sua qualidade narrativa.

O que caracteriza o romance, é um livro que oitenta por cento dele seja direcionado para a relação de homem e uma mulher, homem com homem, mulher com mulher, não importa, uma relação amorosa, que o livro se dê em volta desse relacionamento. Tem livro que é um suspense, pode ter um romance, mas o romance vai acontecer em volta do caso principal, mesma coisa do policial. Essas autoras todas que eu falei, todas elas o romance é o principal na história (Juliana, 26, secretária).

No tempo que eu lia "Os tons de cinza", eu li este livro duas vezes seguidas. Depois eu li "O irresistível cretino" que eu achei que foi a mesma coisa dos "50 tons", só mudou mesmo a personagem. Depois li "Se você quiser" que também é uma história sex, picante-romântica, também muito parecida com os "50 tons". A gente observa que as pessoas mudam as histórias (Antônia, 57, editora).

Acho que nos romances de banca não tem isso (a preocupação em um só tradutor, nos livros mais caros, realizar a tradução de uma autora), a única que já percebi que tem são nesses livros mais caros e o pessoal tem uma preocupação maior , principalmente a Bertrand, é a melhor em termos de tradução (Juliana, 26, secretária).

Os depoimentos acima demonstram um claro conhecimento dessas mulheres sobre o gênero. Esta competência se baseia na ideia de que os consumidores de bens culturais são capazes de conhecer traços específicos de seu funcionamento, classificando, qualificando e formando juízos críticos sobre sua essência. As leitoras sabem tudo isso porque sua experiência de leitura contumaz lhes permite reconhecer as regras e normas de configuração desse bem cultural e é isto que lhes garantem, como diria Barbero (1997), sua competência narrativa $^{12}$.

\footnotetext{
12 Barbero (1997) define esta competência em dois tipos distintos de conhecimento: a competência genérica, que se traduz na familiaridade dos consumidores com o gênero, com sua estrutura e conteúdo manifestos e em sua capacidade de se inserir nas rotinas diárias e a competência específica, que pode ser explicada como os conhecimentos especializados relacionados ao enredo e personagens de determinada narrativa ficcional. As nossas leitoras possuem, portanto, estes dois tipos de competência.
} 
Mas, ao contrário do que apregoa a crítica especializada, para essas mulheres, os romances sentimentais não são todos iguais. No interior do gênero, há subgêneros, traços estilísticos distintos e formatos diversos. As leitoras entendem estas subcategorizações, fazem classificações próprias, comparam formatos, estilos e plataformas diferentes. Há, segundo nossas leitoras, os romances contemporâneos, os sobrenaturais e os históricos, os erotizados e os romantizados, os de livraria e os de banca, os "água com açúcar" e os "hot adultos", os mais "velhos" e os mais "novos", os "digitais" e os "impressos".

A comunidade leitora destes romances constrói, assim, a sua própria hierarquia de leitura. Ao dividi-los em categorias, estas mulheres expõem suas preferências que podem continuar as mesmas no decorrer dos anos ou podem se transformar. Quando mudam de estilo, as fãs entendem esta mudança como uma evolução, uma vez que, em geral, esta transição significa passar dos romances de banca de revista, de menor prestígio social, para os romances de livraria, de maior legitimação no social. Segundo Bourdieu (1979), o gosto, a preferência de um dado grupo de indivíduos por um bem cultural em detrimento de outro, é delimitado pelo lugar social que os indivíduos ocupam na hierarquia social. Assim, uma forma de se adquirir um maior status é consumir bens ou produtos historicamente relacionados às classes ditas "cultas", "eruditas", "superiores". Neste contexto, a troca de "romances de banca de revista", usualmente mais baratos, por "romances de livraria", notadamente mais dispendiosos, alça os fãs de romances de amor a posições sociais mais elevadas em suas comunidades de leitura.

Quando eu comecei a ler, ele era um "Júlia", mas eu fui lendo, fui lendo... Eu só gostava de ler "Sabrina", não sei porque mas, pra mim, a história da "Sabrina" era melhor. Primeiro, "Sabrina", em segundo lugar, "Bianca" e só em terceiro lugar, "Júlia". Aí, quando começou a aparecer os "Paixões", eu dava dinheiro à Dani pra ela trocar os livros pra mim. Ela sabia mais ou menos do jeito que eu gostava do livro, aí a Dani começou a trazer Paixões. Aí aos poucos, eu fui começar a ler os Paixões e agora eu não leio mais "Sabrina", nem "Júlia", nem "Bianca”. Não gosto mais (Carla, 38, costureira).

Eu passei muito tempo lendo romances do estilo "Sabrina", "Júlia", depois comecei a ler Sidney Sheldon, agora estou lendo a Nora Roberts... Muito variados. Os romances estilo "Sabrina" são muito repetitivos. Os homens são sempre lindos, maravilhosos e irresistíveis e você já imagina o final, nessas outras você tenta descobrir o final. O que eu pegar, for romance e empolgante, eu leio (Antônia, 57, editora).

Sim, eu estou em fases, tem época que estou para os policias. Leio livro de banca, os "Paixão", tem os contemporâneo, tem os históricos, que é os que eu gosto mais. Tem os de livraria, aí tem os policiais, os históricos, os sobrenaturais, tem toda essa linha. Eu sou bem eclética eu não tenho problema, eu gosto de coisas diferentes (Karla, 40, revendedora de material de laboratório). 
Essas mulheres iniciam sua entrada no universo dos romances sentimentais, no início da adolescência, entre os 12 e os 15 anos de idade. Em geral, nossas leitoras competentes começaram seu processo de leitura dos romances sentimentais incentivadas por colegas de escola, vizinhas, mães, tias, avós. A leitura de romances, em geral, é um hábito, que passa de mãe para filha, de irmã mais velha pra irmã mais nova, de amigas para amigas. "Com uns 14 anos, foi quando comecei. Foi a minha mãe que já lia na infância dela e a minha irmã mais velha lia também, aí passaram para mim e depois eu passei para as minhas amigas" (Suzanne, 23, demonstradora). Assim, a leitura de romances, é, primordialmente, um ato de socialização, quer seja no espaço doméstico, com mães, tias, avós, irmãs, quer seja no espaço público, com vizinhas e amigas, bem como um rito de passagem que indica a saída da meninice para o mundo adulto.

15 anos por aí... porque a minha mãe lia. A minha mãe sempre teve muitos livros de romances lá em casa. Minha mãe lia muito. Aí por estar perto, criei a curiosidade de ler. Aí, eu passei a pegar os livros dela para ler. Hoje em dia, eu leio mais do que ela (Jordana, 28, desempregada).

Eu comecei a ler, tinha uns 13 anos. Eu tinha achado um livro na casa da minha avó, que estava no quartinho dos fundos, eu bagunçando encontrei esse romance. Não lembro do titulo, só um pouco da história (Danielle, 26, funcionária pública).

Estas leitoras, com idades variadas, iniciaram suas leituras, em geral, pelos livros populares, vendidos em banca de revista. Em especial, os chamados "Romances do Coração ${ }^{13}$ ", livros, de baixo custo, vendidos em bancas de revista, publicados em fins dos anos de 1970 até fins dos anos de 1990 no Brasil e ainda hoje encontrados em sebos e disponibilizados em sites especializados neste tipo de leitura na internet. O preço accessível do livro permitia o seu consumo por adolescentes ao mesmo tempo em que a troca em sua comunidade leitora ou nas bancas de revista facilitava a continuidade do hábito. De qualquer forma, o colégio era o lócus no qual os livros eram publicizados e o interesse despertado e na banca de revista o fenômeno literário era materializado (ANDRADE e SILVA, 2020).

Assim, essa leitura, iniciada na adolescência, teve um papel substancial para as essas meninas na transição para o mundo adulto, uma vez que, moldaram este processo, lhes dando referenciais para definirem quais seriam os comportamentos sociais adequados

\footnotetext{
${ }^{13}$ Os romances sentimentais de banca de revista surgiram, no Brasil, em 1977, através do que a editora Abril Cultural chamou de "Romances do Coração" que abarcaram as coleções "Julia, Sabrina, Bianca e Barbara Cartland", sucessos editoriais entre os anos de 1980 e 1990, se tornando rapidamente ícones de uma geração e sinônimo de romance de banca de revista no Brasil. Não é, pois, à toa que o consumo destes livros retrata, como relatam os depoimentos, o aparecimento da sociedade leitora contemporânea do gênero no Brasil.
} 
nas relações com o sexo oposto (RICKER-WILSON, 1999). Desta forma, os romances Julia, Sabrina e Bianca marcaram uma época e foram responsáveis, em parte, pela formação amorosa das adolescentes nos anos de 1980 e 1990, lhes dando modelos para entender quais os comportamentos socialmente sancionados nas relações entre os sexos. Estes romances foram, pois, considerados pelas gerações anteriores como verdadeiros manuais da gramática amorosa em fim de século. Esta identidade de gênero, apesar de ser formada em várias instâncias diferentes da vida (trabalho, família, escola, mídia) está fortemente ancorada nas práticas culturais das quais o hábito de ler romances, é para este grupo de mulheres, prática indissociável de seu cotidiano.

Eu estudava no período da tarde e eu via as meninas da $7^{\mathrm{a}}, 8^{\mathrm{a}}$ série, lendo Júlia, Sabrina e Bianca (Carla, 38, costureira).

Eu acho que eu tinha os meus 14 pra 15 anos. Eu vi uma colega do colégio com um livro, aí eu pedi pra mim ler. Aí pronto, daí eu não parei mais não. Já era romance, na época...Eu acho que ela tinha comprado na banca, né? porque a gente morava no interior do Quixeramobim. Aí lá, nem banca de revista eu nunca tinha visto, eu vim ver, a partir do momento que a gente veio embora pra cá, pra Fortaleza (Flávia, 36, modelista)

Desta feita, as influências de amigas, na escola, leitoras de romances de amor, foram cruciais para a tomada da decisão da leitura. De outra parte, o acompanhamento de histórias de amor em outros suportes, como nas revistas em forma de fotonovelas e no cinema, foram também fatores decisivos na inoculação do hábito. Para a geração mais antiga, o consumo de fotonovelas, que vinham publicadas em revistas como "Capricho" e "Sétimo Céu", facilitava a continuidade do hábito em uma nova plataforma, o livro. Para as gerações mais jovens, o hábito de acompanhar histórias de amor no cinema orientou a leitura para os romances, uma vez que, muitos deles se transformaram em campeões de bilheteria. Assim, temos aqui o fenômeno de uma convergência tecnológica ${ }^{14}$ que permite a migração de uma plataforma para a outra, estabelecendo uma função de convivência e de complementaridade de narrativas, meios e veículos.

Foi no auge do Harry Potter (quando comecei). Li todos os três, na época só tinha lançado três e fiquei órfã (se referindo aos livros) fiquei "Meu deus o que é que eu vou ler", "não tem nada para ler" e aí, a mãe da minha vizinha que era a Carla, falou para ir na Carla: "Vai lá, ela tem uma estante cheia de livros, vai que tu gosta". Fui à casa da Carla, vi aquela estante dela linda cheia de livros e escolhi um. Carla me perguntou se só ia levar um, eu disse "Acho que vou demorar", aquela coisa, achava que não ia gostar daquela literatura. Cheguei em casa comecei a ler, li rapidinho em uma tarde eu li, voltei para pegar mais um, na terceira vez que fui, saí de lá com treze livros" (Rafaela, 22, estudante).

\footnotetext{
${ }^{14}$ A convergência tecnológica deve ser entendida como a chegada de um vasto cenário de instrumentos que desempenham ou podem desempenhar, funções técnicas assemelhadas ou complementares (SQUIRRA. 2005).
} 
Foi por volta dos 15, já lia por conta do colégio, começando por Nicholas Sparks, após ver o filme "Uma Carta de Amor" (Paula, 28, desempregada).

O consumo destes livros parece crescer em proporção geométrica à medida que o hábito esteja inoculado. Este hábito se forma a partir do consumo das inúmeras coleções que já foram editadas no Brasil, desde a Biblioteca das Moças (1920-1960) ${ }^{15}$ aos romances de banca de revista dos anos de 1980, também chamados por sua comunidade leitora, de romances "Florzinha" até chegar às coleções "Paixão" e "Desejo" da contemporaneidade, herdeiras desses romances de banca. A denominação "Romance Florzinha", expressão criada pelos fãs do gênero, significa, por um lado, que os romances ali inclusos não devem possuir cenas sexuais mais ousadas, apesar da existência, de beijos e trocas de carícias entre os protagonistas. Por outro lado, de forma pejorativa, estes são definidos como uma narrativa na qual a protagonista, "burra e tapada", tem uma atitude passiva perante o protagonista arrogante e prepotente, exibindo pouca disposição para a luta ou o confronto.

É o que a gente chama de florzinhas, em que geralmente os homens são arrogantes ao extremo, e as mulheres são burras, tapadas, eles fazem o diabo a quatro com elas e para elas está tudo bem, mas eu tinha que ler. Hoje em dia não, eu posso ler o que eu quiser, geralmente eu opto por mocinhas mais inteligentes, de vez em quando ainda leio um desses romances que me fazem raiva (Rafaela, 22, estudante).

O hábito de ler romances é tão arraigado que suas leitoras chegam a defini-lo como uma droga, que faz falta, quando a dose diária não é tomada. O consumo de romances, por parte das mulheres entrevistadas, é espantoso, tendo em vista a ideia partilhada pelo senso comum de que os brasileiros leem pouco. As mulheres entrevistadas leem, em média, entre quatro a doze romances ao mês, com um ritmo de leitura diário ou quase diário.

Todos os dias, só varia a quantidade de tempo que eu leio, mas todos os dias eu leio nem que seja uma parte pequena (Danielle, 26, funcionária pública).

Quando eu comecei, foi nessa coisa mais básica, tipo o água com açúcar. Quando eu tava bem no início da adolescência, lia também Biblioteca das Moças, a série Florzinha depois. Foi aí quando se tornou realmente um hábito de ler todos os dias que é meio que uma droga que faz falta quando você não lê (Alexandrina, 30, gerente de marketing).

A leitura em grandes proporções desses romances- cada romance tem em torno 150 a 250 páginas -a depender da coleção onde está inserido - significa que estas mulheres desprendem um tempo valioso de suas vidas à leitura, ao mesmo tempo em que indica uma

15 A Coleção Biblioteca das Moças, publicada pela Companhia Editora Nacional, produziu os grandes best sellers românticos no Brasil entre os anos de 1920 e 1960 e era consumida, essencialmente, pelas classes médias dos grandes centros urbanos do País. 
velocidade enorme em seu consumo. Lê-se todos os dias, em dias alternados, no intervalo do trabalho, pela manhã, à tarde e a noite, até de madrugada. Às vezes, consome-se, no caso dos romances de banca de revista, um romance por dia, e muitas vezes, alterna-se a leitura de dois livros ao mesmo tempo. O hábito de ler romances inaugura um ritual cotidiano. Se as mulheres de outros tempos tinham o hábito, todos os dias, de abrir o breviário, para fazer suas orações, as mulheres de hoje têm o hábito de realizar seus ritos de leitura cotidianamente, como uma obrigação sagrada a qual não podem deixar de cumprir.

Olha, eu sempre leio dois livros ao mesmo tempo. Eu sempre estou lendo, não passo uma semana sem ler nada. Exemplo: agora eu estou lendo "A menina que roubava livros", estou lendo "As mulheres que andam com os lobos". Sempre estou lendo um e outro, alternando (Antônia, 57, editora).

Quando eu trabalhava fora, eu lia de manhã, meio-dia e de noite. Final de semana, já aconteceu de eu pegar uma história boa e ler na madrugada. Ainda hoje, se eu pegar um livro bom eu faço isso... A história assim que você fica ansiosa pra poder terminar logo, sabe? (Carla, 38, costureira).

Depende da minha vontade, essa semana mesmo eu terminei esse "Algema de Seda", e aí fui ler "Regresso". Esse livro é de livraria, mas se você for observar, eles são romances de banca que foram publicados em formatos de livros. Eu li dois em dois dias. Leio um romance de banca por dia (Karla, 40, Revendedora de material de laboratório).

A avidez pela leitura, típica das fãs de romances sentimentais, nos faz situá-las no que Chartier (1988a) chama de leitura extensiva. Para este autor, esta se inicia, na Europa, a partir da primeira metade do século XIX, quando o mercado editorial, já consolidado, faz proliferar o acesso a numerosos livros, lidos numa relação individual e silenciosa. É uma leitura laica que determina o seu afastamento das celebrações religiosas, eclesiais ou familiares ao mesmo tempo em que se passa de um texto a outro, não se tendo mais apreço pelo objeto impresso cujo destino é ser abandonado ou jogado fora. Esta nova forma de leitura, em tese mais superficial, traduziria um investimento menor no livro e na eficácia dos textos como mestres da vida. Os romances lidos por nossas mulheres, de fato, não guardam, necessariamente, aprendizagens sobre a vida nem sequer sobre o sentimento amoroso, mas propiciam o uso da imaginação, permitem o sonho, e a instauração do encantamento em um mundo desencantado.

Pois é... Não sei! Porque eu gosto... Assim... o irmão da Nina [outra amiga, que conhecemos] sempre chamava a gente de "sonhadoras". "Vocês são sonhadoras, vão botar o pé no chão, vão acordar que isso aí não existe não" Eu sei que não existe, mas o que é que tem eu sonhar? Não é pecado, não faz mal (Carla, 38, Costureira).

A nossa comunidade leitora afirma não ler estes romances porque esperam ter um romance como o da heroína. Nesta perspectiva, a leitura não funciona como um mapa do 
tesouro para encontrar o "amor ideal” ou o "príncipe encantado". Há uma vida real que é diferente da vida descrita nos romances porque esta exige outras estratégias de ação distintas das encontradas nos livros sentimentais. A leitura dos romances não funciona como os antigos almanaques, fornecendo "fórmulas" para uma vida feliz. Assim sendo, 90\% das entrevistadas dizem não fazer relação entre o que leem e sua vida cotidiana. Os homens inteligentes, gentis e fortes dos romances dificilmente se equiparam aos de carne e osso, taxados como verdadeiros "cavalos batizados", com raras e salutares exceções. O poder da leitura, traduzido no senso comum, como capaz de guiar pensamentos e condutas deve ser relativizado no que diz respeito ao âmbito desta pesquisa.

Porque é o meu passatempo favorito e a vida da gente já é assim tão... Tem tanto problema, tanta preocupação. Eu procuro ler romance pra tentar esquecer das coisas que tá acontecendo no dia a dia. Tem gente que acha que a gente lê romance, porque acha que um dia vai encontrar um igualzinho... isso aí eu sei que não existe... Eu gosto, porque você se imagina num outro ambiente, né? Você conhece lugares que você nunca viu, com certeza, você nunca vai poder ir (Lenilde, 26, costureira).

Acho que quando eu estou lendo o romance eu vou viver aquela fantasia que nunca vou viver na vida real, e também os problemas desaparecem, não que eu tenha muitos graças a Deus, aquelas coisas que ficam perturbando o juízo da gente, o stress some, me distrai. Acho que é a questão romântica mesmo, que mulher não sonha com seu próprio conto de fadas, até as mais cínicas não tem como. Eu não acredito em nada disso na vida real, não quero casar, nem ter filho, nunca quis, mas acho que na fantasia tudo é válido é uma forma de tornar a vida da gente mais suave (Juliana, 26, secretária).

Assim, as variações nos regimes de leitura dos romances sentimentais são extensas. Os regimes de leitura são definidos por Chartier (1998b) como o resultado das apropriações que os leitores fazem do livro. Estas apropriações se ordenam e se distribuem em vários regimes de significação e sentido, mas também indicam que os leitores produzem novas ordens de apropriações imprevistas, que de algum modo subvertem a ordenação inicial com que foram modelados e as classificações a que foram submetidos em gerações anteriores. É o que chamamos nesta pesquisa de leitura intervencionista. As leitoras modificam visual e estruturalmente a obra, "apagando", "riscando", "deletando" no texto características de personagens que não agradem aos seus gostos estéticos, como a cor dos cabelos e dos olhos. Ao mesmo tempo em que, apesar dos esforços para modificar algum padrão narrativo ou visual (no caso das capas), nem sempre se obtém sucesso, levando ao abandono da obra.

De primeiro, eu ia pela capa, mas eu aprendi que a capa, às vezes, não é a mesma coisa do conteúdo. Por exemplo, tem um clássico (...) que ele é lindo na capa, moreno. Aí, na história, ele é louro e cacheado! Eu não li. Tentei pintar o cabelo dele, cortar... Não desceu não. Entreguei sem ler. Aí, agora, eu vou mais pelo conteúdo (Carla, 38, Costureira). 
Estas mulheres, ainda que comprem nas redes oficiais de venda os últimos lançamentos do mercado, entrando, inclusive, em contato com os editores que lançam as obras no Brasil, em busca de promoções, materiais de divulgação e descontos, permutam e negociam os romances de "coleções passadas" em bancas de revista ou em sebos bem como estabelecem um circuito de empréstimo no interior da sua própria comunidade de consumo e ainda baixam os livros disponibilizados gratuitamente ou não na rede mundial de computadores. A escolha por comprar ou baixar gratuitamente na rede, comprar em sebos, comprar em banca, comprar em livraria física vai depender do grau de emoção que o livro possa vir a trazer para as suas leitoras.

Eu pego na internet. Os livros de banca compro na banca ou nos sebos, hoje em dia tenho comprado (nas bancas) muito pouco só quando realmente eu gosto da história. Nos sebos, bastante. Quando é livro que quero muito compro logo na banca preço de capa (Rafaela, 22, estudante).

Para os empréstimos acontecerem, a portadora do bem, isto é, o livro, deve ter uma qualidade: não ter apego. Há as leitoras que têm apego (e não emprestam de jeito nenhum), mas há também aquelas que não. Para fazer parte de uma comunidade de leitura, a leitora deve fazer parte da segunda categoria. $\mathrm{O}$ apego se traduz apenas no cuidado com o livro e não no ato de não emprestá-lo. Mas, enquanto se empresta também se acumula livros. Há aquelas que têm estantes inteiras só dedicadas aos livros de amor que podem variar entre 100 a 1000 obras. Há aquelas que colecionam coleções inteiras e há aquelas que optam por autores particulares. Assim, possuindo 100 ou 1000 livros, o pertencimento a uma comunidade faz com estas mulheres sintam a necessidade de trocarem e emprestarem livros continuamente.

Emprestado, com amigos. Eu compro alguns também. Agora, quando a gente compra livro, ele fica parado. Eu passo pra frente, quero que outras pessoas leiam. As pessoas não tem a mesma facilidade de emprestar, eu tenho, passo adiante, não tenho apego, não importa o valor que eu tenha pago. Os livros que eu leio eu tenho um cuidado, sabe (Antônia, 57, editora).

Não abandono nunca os livros de banca tem uma estante que tem quase mil livros de banca por isso que me chamam de acumuladora (Karla, 40, revendedora de material de laboratório).

A maioria dos que eu li é emprestado de uma amiga, que ela tem bem mais do que eu, eu devo ter o que, 160 por ai, ela tem uns 580. Ela tem três estantes. Os de banca eu compro em sebo e os demais na livraria mesmo, pela internet, eu só compro pela internet (Juciara, 22, estudante).

Assim, existe uma lógica que rege as trocas e empréstimos. Em geral, quando se inicia no processo de leitura, estas trocas e empréstimos acontecem com mais frequência, uma vez que, as leitoras não guardavam o nome das autoras, desta feita, os lançamentos no mercado, 
pelo menos de banca de revista eram constantes e, portanto, o livro ainda não era considerado um bem precioso. Mas, se os empréstimos às pessoas fora do círculo mais íntimo eram mais comuns, as perdas dos exemplares também. Este é o maior pesadelo daquela que empresta. $\mathrm{O}$ livro não é somente uma mercadoria, é também um objeto de culto. Não ter mais o seu livro de volta ou recebê-lo com páginas faltando, dobrado ou amassado é uma situação considerada extremamente "doída". Eis porque não se deve emprestar para qualquer uma, mas somente para aquelas que fazem parte da "comunidade".

Eu emprestava muito e, nessa história de emprestar, você acaba perdendo. Aí desde esse tempo, eu não fiz mais conta de colecionar, de guardar. Aquelas histórias que eu gosto mais, eu guardo, as que não, eu passo pra frente (Carla, 38, Costureira).

Eu empresto meus livros, agorinha, eu emprestei um... Eu tenho alguns livros de livraria que são os que gosto muito como Nora Roberts, aí eu emprestei alguns, tipo uns sete livros, aí você empresta e a pessoa nunca devolve. Olha dá uma raiva uma dor no coração 40,00 reais, né... Assim se for esses de banca, tem besteira não, mas se for de livraria que eu paguei de três vezes, fico muito puta da vida (Jordana, 28, desempregada).

Este sistema de empréstimo acontece com a partilha do amor pela leitura, mas somente este amor não é suficiente. O indivíduo destinatário dos empréstimos deve ser antes legitimado pela comunidade. Por outro lado, apesar de adotarem um sistema de empréstimo entre amigos e parentes, o livro é considerado um bem precioso, que não pode ser compartilhado com aqueles leitores fortuitos e/ou que não pertençam à comunidade de fãs do gênero, é o que confirma o depoimento de Marta, agente administrativo.

Um dia estava lendo no ônibus e percebi que estava ficando torta para frente, quando olhei o rapaz que estava atrás de mim estava lendo também o livro. Eu estava logo na parte mais picante do livro, pensei se quiser ler compre o seu, e então fechei o livro (Marta, 32, agente administrativo).

$\mathrm{O}$ ato de guardar livros passa a acontecer somente para aqueles especiais, que se deseja manter e reler. Estas mulheres podem reler um livro, pelo menos, cinco vezes. Não necessariamente para relembrar, mas para reviver a cena. Às vezes, não se lê a obra toda, mas apenas as partes mais emocionantes, porque o livro chama, hipnotiza, atrai. "De vez em quando passo na minha estante e pego um, eu tenho mania de reler as minhas partes preferidas, geralmente tem uma etiquetinha lá, releio minha parte preferida e depois pego outro e aí faço uma misturada louca" (Rafaela, 22, estudante). "Tem alguns que eu já reli umas 5 ou 7 vezes. Não se trata nem de relembrar, e sim de reviver a cena. As vezes eu não releio todo o livro, só algumas partes" (Lucivania, 24, desempregada). 
Estes livros prediletos, sempre relidos, contestam a ideia de Chartier (1998a) de que um tipo de leitura tão ávida levaria seus leitores a jogarem fora ou abandonarem todas as obras oriundas deste processo. Se é verdade que no mundo dos romances, muitas obras são vendidas/trocadas depois de lidas, outras não tem este destino. As leitoras costumam guardar consigo exemplares do que consideram os "melhores romances", que se tornam bens preciosos, ornamentando estantes, em lugares de destaque em seus lares. Mas, com o acúmulo de livros, arranjar novos espaços nos lares se torna um problema complicado. Por outro lado, os livros são objeto de ciúmes. O livro é um bem amado e deve ser tratado com apreço por aqueles que não são seus donos. Ao mesmo tempo em que este cuidado se dá por conta da história do livro, valorada como excelente, o preço da obra emprestada também é um fator importante. Obras mais baratas são mais facilmente emprestadas do que obras mais caras porque se danificadas ou perdidas, doem mais no bolso. Nada de doar livros, guarda-se vende-se, empresta-se ou troca-se.

\footnotetext{
Doar é uma palavra que não existe no meu mundo. Eu guardo na minha estante. Emprestar, só se minha amiga assinar um contrato garantindo que vai voltar do mesmo jeito que foi, se não é morte. Mulher, eu tenho muito ciúme dos livros. Eu acho que o meu namorado, o antigo né, ele morria de raiva disso, porque eu não tinha ciúmes dele, mas eu tinha ciúme dos meus livros (Juciara, 22, estudante)
}

Morro de ciúme da minha coleção. É uma coleção nova relativamente, foi lançada em 2008 nos Estados Unidos, chegou aqui em 2010. Está lá na minha estante, morro de ciúmes dos meus livros, emprestei para minha vizinha que me emprestava romances, mas emprestei para devolver no outro dia, emprestei o primeiro chorando (Rafaela, 22, estudante).

Porém, se os empréstimos sempre estão presentes as trocas, no centro da Cidade ou em sua própria comunidade de leitura são uma constante na trajetória de vida destas mulheres. Toda uma geração de leitoras se formou a partir da troca de livros, nas praças do centro da Cidade, nas quais se congregava o maior número de bancas da cidade. Se o início do processo de leitura, os livros eram oriundos de empréstimos de familiares ou amigos, quando as garotas adquiriam autonomia de deslocamento, elas passavam a comprar os livros em sebos e trocarem os exemplares nas bancas do centro da Cidade. O sistema de trocas facilitava a continuidade do hábito porque era a forma mais barata aquele tempo de ter acesso ao bem, ainda que, nem sempre em boas condições de conservação. Ali, estabelecia-se um verdadeiro mercado de troca e venda de exemplares.

Aí eu li, menina, aí eu comecei a comprar esses livros de banca, aí eu comecei, aí comprava. E quando estava com um bocado, aí levava na banca e trocava. É que nessa época, não tinha computador, não tinha essas coisas de e-book. Não tinha 
essas facilidades todas. Aí, era assim, eu ia no centro, trocava 20 livros. Ia pra casa, passava uma semana lendo. Aí depois, passava um tempo sem ler por que não tinha mais livros, não podia ir sempre. Aí depois, comecei a comprar alguns livros (Caroline, 35, design).

Geralmente, os de banca, eu tenho o costume de guardar, geralmente os livros que eu troco são aqueles que eu não gosto, é melhor trocar do que vender, é mais jogo. Porque para vender, eles querem comprar muito barato. Quando é para trocar você tem a opção de não dá dinheiro, você troca. Então, é melhor trocar porque, ás vezes, quando você vende não dá nem para comprar um livro de banca, então, não é vantagem vender é melhor trocar (Rafaela, 22, estudante).

A avaliação do vendedor de banca do livro que se pretende trocar depende também de uma compreensão típica do "mundo das vendas" que se baliza na percepção que o vendedor faz da intensidade do desejo de compra por parte da cliente como também do estado de conservação do livro, apesar de que tais critérios não são aplicados a todas as negociações. Por outro lado, competências específicas dos livreiros sobre as regras e formas do gênero, assim como a experiência adquirida a respeito das coleções mais procuradas e autores mais desejados também entram na pauta de negociação.

Assim, tanto a compra direta como os mecanismos de troca requerem uma complexa estratégia de valorização/desvalorização do livro realizada por ambas as partes, em momentos diferentes do processo, que, obviamente, tem como fim último, a "pechincha". Estas estratégias de valorização, do livro a ser "vendido" de um lado e desvalorização do livro a ser "trocado" de outro e vice-versa, exigem do vendedor certo conhecimento da estrutura do romance e de seu peso em suas comunidades de leitoras. Em muitas bancas, a pesquisa constatou que os vendedores são bons conhecedores dos produtos que vendem, tornando o jogo da "pechincha", uma verdadeira "luta de titãs".

Neste sentido, esta competência pode ser lida no próprio processo de seleção das obras a serem consumidas. A maioria de nossas experts selecionam os livros a serem comprados a partir do resumo publicado na anticapa, a partir do conhecimento e ou recomendação de um autor específico ou a partir das imagens das capas, apesar de que a indicação de parentes/amigos também pese na decisão. Mas, os resumos guardam armadilhas, muitas vezes, não correspondendo à trama. As capas, às vezes, nada tem a ver com a história ou com as personagens. A seleção pelo conhecimento de autores apreciados pelas leitoras, nem sempre dá certo. Assim, a escolha do livro a ser comprado é sempre uma equação complexa.

É um composto de coisas que me auxiliam, autor porque através do autor já tenho uma noção do que vou encontrar. Há outra coisa, a indicação é muito importante. Como eu participo de muitos grupos de leitura e tenho muitos amigos que leem, aí vou fazendo uma triagem porque quando você recebe um comentário positivo de uma pessoa que ler os mesmos livros que você fica mais fácil. A capa, às vezes, 
porque sei que capa não diz muito. Já peguei livros com a capa maravilhosa, com conteúdo que não gostei como também já peguei capa horrorosa, mas que o livro era maravilhoso (Alexandrina, 30 anos, gerente de marketing).

O resumo é muito importante, o autor também. Exemplo, os livros do Sidney Sheldon, só teve um livro dele que eu não gostei que foi "Espelho", mas os demais livros deles são ótimos (Antônia, 57, editora).

Geralmente, eu me apaixono pelas capas, chamam muito atenção. Hoje em dia, acho que o pessoal percebeu que as capas vendem muitos livros também, então elas tem investido mais nas capas. Eu olho a capa, se eu gostei muito da capa, aí eu vou e leio a sinopse, aí se a sinopse for interessante, eu compro. Eu olho a capa e a sinopse (Rafaela, 22, estudante)

Contudo, como as nossas mulheres sabem dos lançamentos da área? As nossas entrevistadas acompanham o mercado das publicações, por informações de amigos, por telefonemas para as bancas que frequentam, indagando sobre os lançamentos, pelos comentários no facebook, por pelas páginas das editoras na rede e nas buscas nas livrarias físicas. Assim, os meios e veículos de informação são os mais variados possíveis. Em geral, as comunidades usam várias destas combinações. Mas, seja como for, as informações adquiridas são sempre compartilhadas em circuitos maiores. As informações também são enviadas por e-mail para as fãs, e para as que possuem blog, com muita assiduidade. Desta forma, todo o ciclo de produção e consumo se completa.

Acompanho as publicações através dos amigos. Apesar de está ficando mais velha, eu me envolvo (Antônia, 57, editora).

Aí toda semana, eu tô ligando, aí, se eu não for pro Centro, eu ligo pro Azevedo [dono de uma banca de revistas, que fica na Praça dos Leões, centro de Fortaleza]... Eu também vou na banca Cláudia, mas é mais no Azevedo mesmo, porque eu conheço o Azevedo desde a época que a gente veio do Quixeramobim. Como eu tô colecionando os Paixões, aí eu tô sempre seguindo, quando acontece de não vir pra banca uma numeração, aí eu fico perguntando pra ele e, quando chega, eu compro. Eu tô também sempre dando uma olhadinha no site da editora e, todos os livros, nas costas dele, dentro, tem dizendo as próximas edições (Flávia, 36, modelista).

Pelo face, pelas comunidades que a gente tem pelo facebook, as páginas, com as próprias editoras que eu tenho contato com algumas por lançamento de livros. Aí, as editoras também me mandam os lançamentos por mês (Juciara, 22, estudante).

A Harlequim manda informativos mensais para o e-mail da gente, a gente sempre olha o site. Sempre pela internet, como eu tenho blog, eu recebo as novidades para postar. Eu sou uma forma de divulgação deles também. Livraria eu vou muito, e vejo, mas antes de ver lá, eu já vi em outros cantos. Não compro em livraria só pela internet que é mais barato (Juliana, 26, secretária).

Geralmente, eu olho o grupo daquelas meninas (ARF), se for alguma série que eu já tenha começado, eu pesquiso no google pra saber sobre o lançamento do próximo" (Danielle, 26, funcionária pública)

Eu não só acompanho como também me sinto parte do mercado. Sou uma das pessoas que brigam para que a tradução não seja censurada, que seja fiel aos originais. Isso tudo por causa da era digital na qual estamos passando, a 
possibilidade de ler os livros em seus formatos originais, sem contar da facilidade que hoje se tem de baixar um livro e também os grupos de tradução querem trazer para uma tradução de fã para fã (Alexandrina, 30, gerente de marketing).

Quando eu tinha mais tempo, até traduzia livros da $\mathrm{JR}^{16}$. Há algum tipo de perseguição das editoras. Antigamente não, porque os livros que traduzíamos não era a linha que as editoras daqui tinha. A partir do momento que nós leitoras passamos a pedir que essas editoras publicassem esse tipo de linha é que começou a perseguição, antes existia mais umas picuinhas entre os grupos de tradução (Alexandrina, 30 anos, gerente de marketing).

É, geralmente pelos blogs, acho que quase todos esses sites de editoras que a gente pode cadastrar e-mails para receber as novidades, né, então recebo e-mails. Aí, vou só aumentando a lista dos desejados no Skoob, aí é desse jeito (Paula, 28, atendente).

Indubitavelmente, a leitura destes livros é parte importante do cotidiano destas mulheres. Este cotidiano é visto como cheio de cuidados e responsabilidades. Muitas delas têm duplas jornadas de trabalho. No lar, organizam o serviço doméstico, cuidam das necessidades de marido e se for o caso, filhos. Elas são as responsáveis pelas compras domésticas, pelos cuidados físicos com a casa, pela organização da agenda familiar, pela manutenção da saúde da família (são elas que marcam e desmarcam consultas médicas). Muitas vezes, assumem responsabilidades que saem de sua família nuclear e se voltam para sua família de origem. Estas gerenciam muitas atividades oriundas da casa da mãe, da irmã, da cunhada e das tias. Quando solteiras, têm, além de atribuições no trabalho, as do espaço doméstico. Assim, o livro de amor é o refúgio no qual os aborrecimentos, comuns à vida de todos os dias, tendem a desaparecer. É um espaço no qual a fantasia encontra lugar, se opondo à realidade, com seus problemas e dificuldades. O lar, como refúgio, ilha de felicidade (LIPOVESTKY, 2000), só pode ser encontrado nas páginas dos romances.

Eu acho que é pra desestressar. É minha válvula de escape. Se eu tô com raiva, eu pego um livro vou ler e pronto, passou. Se eu tô com dor de cabeça, eu pego um livro e pronto, passou. É uma válvula de escape mesmo pra mim, me desestressa total. Se eu quiser matar alguém, eu pego um livro e leio e a vontade diminui (Juciara, 22, empregada de loja).

Acho que quando eu estou lendo o romance eu vou viver aquela fantasia que nunca vou viver na vida real, e também os problemas desaparecem, aquelas coisas que ficam perturbando o juízo da gente, o stress some, me distrai e na fantasia tudo é válido é uma forma de tornar a vida da gente mais suave (Juliana, 26, Secretária).

\footnotetext{
${ }^{16}$ A entrevistada está fazendo referência à sua participação nos autodenominados Projetos de Democratização da Leitura (PDL) vigentes no País. No caso em destaque, trata-se de uma iniciativa, sem fins lucrativos, idealizada, organizada e administrada de forma amadora por fãs do gênero que se utiliza de mão de obra voluntária para efetivar a transcrição, tradução (se for o caso) e circulação de estórias de amor entre seus leitores à revelia das suas editoras, rompendo, em muitos casos, com os diretos autorais das obras. Os e-books domésticos e artesanais podem ser encontrados nos inúmeros sites de discussão do gênero existentes no Brasil.
} 
A gente sabe que é história, mas muita gente não entende que, quando você tá lendo, é como se a cena tivesse acontecendo na sua frente, como se você estivesse sentada lá, observando, aí você tem vontade de dar uma tapa, de fazer isso ou aquilo, de argumentar, de dizer "faz isso" ou "não faz isso (Carla, 38, costureira).

Esta procura pelo prazer, pela felicidade ou pela alegria é um dos traços fundamentais do lazer na sociedade contemporânea. Não é à toa que o hábito de ler romances sentimentais é encarado por nossas entrevistadas como uma atividade relacionada ao binômio lazer/prazer. Se para Dumazedier (1979), o lazer é, na era moderna, concebido como uma atividade fora do tempo de trabalho, no tempo desocupado que complementa e compensa o indivíduo da faina diária, para nossas mulheres, o lazer ao mesmo tempo em que ocupa o espaço destinado ao relaxamento e à distração da labuta, é o exercício da liberdade. As mulheres desta pesquisa traduzem o ato de ler romances sentimentais como um "momento só para si". A leitura de romances compreende, assim, a oportunidade de demarcar um espaço e um tempo somente seu dentro de seus inúmeros afazeres e encargos diários e emocionais.

Desta feita, os atos de leitura dos romances sentimentais possuem um itinerário que orienta os limites e desafios de sua produção, circulação e consumo. Esta literatura, como prática cultural, se incorpora a um amplo leque de rituais, processos, interações sociais dos mais diferentes matizes (ANDRADE e SILVA, 2020). Porém, ainda que se atribua um valor relativo ao romance sentimental - ele é vendido, trocado, emprestado, abandonado - ou especial -ele é conservado, idolatrado, idealizado -, não podemos nos furtar de indagar qual seria a razão pela qual na estação dos amores voláteis, fundada em relacionamentos a dois de caráter tão passageiro, se lê ainda tanto romance. Quem gostaria de responder?

\section{Referências}

ANDRADE, Roberta Manuela Barros; SILVA, Erotilde Honório. Um século de romances de amor: a trajetória da literatura sentimental no Brasil (1920-2020). Columbia: Independently Published, 2020.

BARBERO, Jesus Martin. La telenovela en Colombia: melodrama, televisión y vida cotidiana. Revista de la Federación Latino Americana de Associaciones de Faculdades de Comunicación Social, No.17, junho de 1997.

BOURDIEU, Pierre. La distinction: Critique sociale du jugement. Paris: Minuit, 1979.

CHARTIER, Roger. Du livre au livre. In: Réseaux. Paris: Editions Rivages, volume 6 n³1. pp. 39-67, 1988a. 
CHARTIER, R. S. A ordem dos livros: leitores, autores e bibliotecas na Europa entre os séculos XIV e XVIII. Brasília. Universidade de Brasília, 1998b.

COPES, Regina Janiakis. Políticas Públicas de incentivo à leitura: um estudo do projeto "Literatura em minha casa". Dissertação de Mestrado. Universidade Estadual de Ponta Grossa. Departamento de Educação, 2007.

CROPANI, Ottaviano de Fiori. Livro, biblioteca e leitura no Brasil. Brasília, 1998. Disponível em: htpp: //www9.cultura.gov.br; textos/of01,htm. Acessado em março de 2011.

DUMAZEDIER, Joffre. Sociologia empírica do lazer. São Paulo: Perspectiva, 1979.

FISKE, John. Bristish cultural studies and television criticism In: ALLEN, Robert C. (org): Channels of discourse: television contemporary criticism. London: Methuen, 1987.

JAUSS, H.R. Pour une esthétique de la réception. Paris: Gallimard, 1978.

LIPOVESTKY, G. A terceira mulher: Permanência e Revolução do Feminino. São Paulo: Companhia das Letras, 2000.

RADWAY, Janice. Reading the romance: women, patriarchy and popular literature. London: Verso, 1987.

RICKER-WILSON, Carol. Busting Textual Bodices: Gender, Reading, and the Popular Romance. IN: The English Journal, vol. 88, No. 3, Genderizing the Curriculum, Janeiro, 1999.

SAMONÀ, Carmelo: Los códigos de la novela sentimental. In: Historia y crítica de la literatura española. (História e crítica da literatura espanhola). Barcelona: Crítica, 1980.

SODRÉ, M. Teoria da literatura de massa. Rio de Janeiro: Tempo Brasileiro, 1978.

SOUZA, Jorge Pedro. Elementos de Teoria e Pesquisa da Comunicação e dos Media. Porto: Letras Contemporâneas, 2006.

SQUIRRA, Sebastião Carlos de Moraes. A convergência tecnológica. IN: Revista Famecos. Porto Alegre, agosto de 2005. 